\title{
Xylella Fastidiosa Diseases and Their Leafhopper Vectors ${ }^{1}$
}

\author{
Russell F. Mizell. Peter C. Andersen, Christopher Tipping, Brent Brodbeck ${ }^{2}$
}

\section{Introduction}

As its name implies, Xylella fastidiosa (Fig. 1) is a fastidious (hard to culture), bacterium that resides in the plant xylem tissue. It is vectored (spread) almost exclusively by xylem feeding leafhoppers. Strains of this bacterium are the causal agent of phony peach disease (PPD), plum leaf scald, Pierce's disease (PD) of grapes, citrus variegated chlorosis (CVC), and leaf scorch of almond, coffee, elm, oak, oleander pear, and sycamore. Diseases caused by X.Fastidiosa are most prevalent in the southeastern United States, but may also occur in California, southern Ontario, and the southern midwestern states. In north Florida, PPD and PLS can limit peach and plum orchard life. European varieties of wine and table grape are virtually non-existent in the Southeast due to PD, while cultivars of muscadine grapes are resistant. Outbreaks of diseases caused by $X$. fastidiosa can be expected to occur whenever conditions are favorable for the spread of the disease within and between plants, including seasonal rainfall and other factors affecting leafhopper populations. Presently, grape production in California is threatened by Pierce's disease because of the recent introduction of an efficient leafhopper vector of $X$. fastidiosa, the glassy-winged sharpshooter, Homalodisca coagulata (Fig. 2).

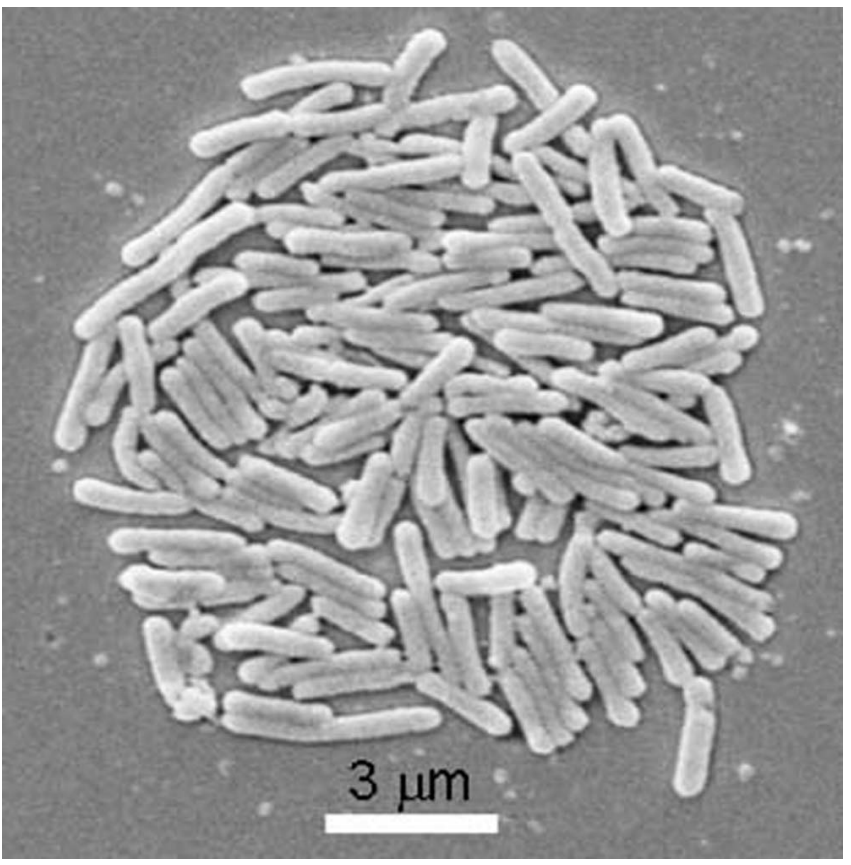

Figure 1. Xylella fastidiosa, the causal agent of Pierce's and other diseases. Credits: Dr. Eduardo Alves

1. This document is ENY-683, one of a series of the Department of Entomology and Nematology, Florida Cooperative Extension Service, Institute of Food and Agricultural Sciences, University of Florida. Publication date: October 2003. Please visit the EDIS Website at http://edis.ifas.ufl.edu. Figure 1 was provided by Dr. Eduardo Alves.

2. Russell F Mizell, professor, Entomology and Nematology Department, Peter C. Andersen, professor, Horticultural Scineces Department, Christopher Tipping, post-doctoral researcher, Brent V. Brodbeck, senior biological scientist; North Florida Research and Education Center - Quincy, Cooperative Extension Service, Institute of Food and Agricultural Sciences, University of Florida, Gainesville, 32611.

The Institute of Food and Agricultural Sciences (IFAS) is an Equal Opportunity Institution authorized to provide research, educational information and other services only to individuals and institutions that function with non-discrimination with respect to race, creed, color, religion, age, disability, sex, sexual orientation, marital status, national origin, political opinions or affiliations. U.S. Department of Agriculture, Cooperative Extension Service, University of Florida, IFAS, Florida A. \& M. University Cooperative Extension Program, and Boards of County Commissioners Cooperating. Larry Arrington, Dean 


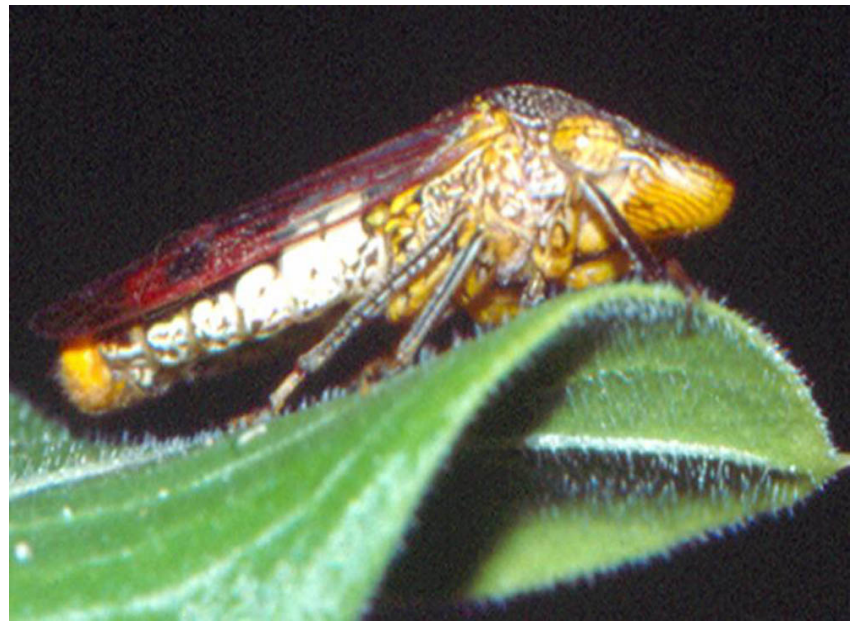

Figure 2. Homalodisca coagulata, the glassy-winged sharpshooter, a major vector of Xylella fastidiosa.

$X$. fastidiosa multiplies and spreads slowly up and down the xylem of the tree from the site of infection. Populations of $X$. fastidiosa restrict water movement in the xylem, but the true biochemical and biophysical mechanisms involved in symptom manifestation remain unknown. $X$. fastidiosa bacteria are also plentiful in the roots of infected peach and plum trees and can be transmitted by grafting and possibly by root grafts in nature. Grafting experiments and microscopic examination of the xylem indicate that a few $X$. fastidiosa bacteria are present in the infected stems during much of the year. Symptoms can develop as late as 18 months or more after initial infection of peach and may develop in one scaffold limb or over the entire tree at the same time. An extremely dry summer seems to delay the development of symptoms for at least a year.

\section{Plum Leaf Scald and Phony Peach Disease}

Peach trees with symptoms of PPD were first noticed throughout the South about 1890. Infected peach and plum trees bloom several days earlier than healthy trees and tend to hold their leaves later into the fall. Early in July, because of shortened internodes (Fig. 3), infected peach trees appear more compact, leafier, and darker green than normal trees. In addition to reductions in overall quality and yield, individual fruits are drastically reduced in size. Also, fruit may be more colorful and will often ripen a few days earlier than normal. The leaves of infected peach never display the typical scorched or scalded appearance that is diagnostically typical of leaves from infected plum trees (Fig. 4). Trees that develop PPD symptoms before bearing age never become productive. PPD does not kill the tree but may make it more susceptible to other diseases and arthropods. Plum leaf scald also increases tree susceptibility to other problems but will kill infected trees. Leafhoppers feed extensively on plum cultivars such as Santa Rosa and Metheley, cultivars that are highly susceptible to the bacterium.

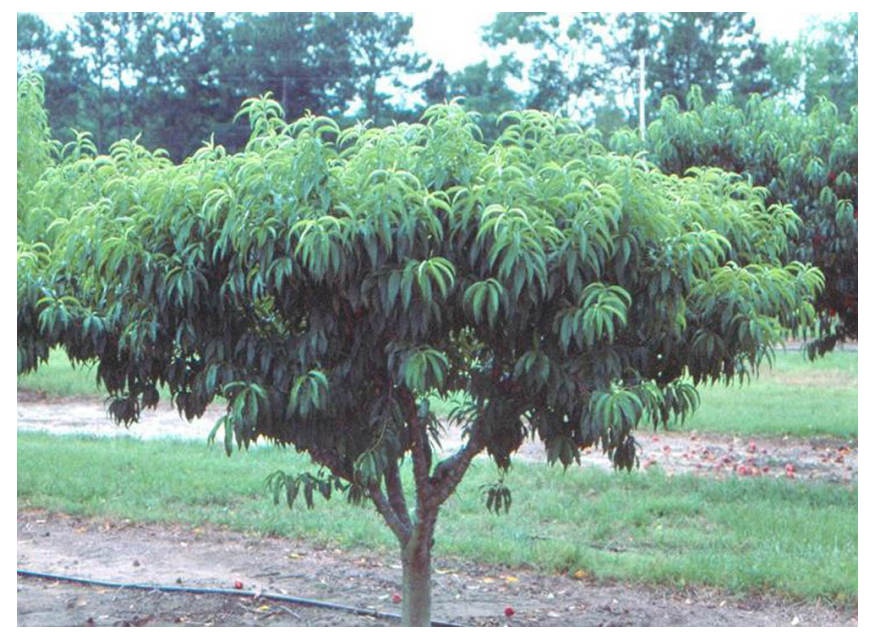

Figure 3. A peach tree expressing systems of phony peach disease.

\section{Leaf Scorch}

Leaf scorches occur with similar symptoms in plum and many ornamental trees including elm, oak, sycamore, and maple. Often the leaves will appear normal early in the season, but later develop a tan discoloration beginning at the leaf margin that spreads in an uneven band toward the midrib and base of the leaf. The dead leaf tissue is separated from living green tissue by a narrow but distinct yellow border or halo (Fig. 5). Disease will often stress and weaken the tree, predisposing it to attack from insects and fungi. Although it requires several years for the bacterium to kill trees, branch dieback and tree death eventually occurs, depending on the vigor of the tree. The occurrence of leaf scorch has increased to epidemic levels in the last 10-15 years in the middle-Atlantic states where it is destroying valuable large shade trees. Sycamore leaf scorch is particularly devastating because, in addition to affecting shade trees, it prohibits the development of sycamore plantations for fiber production. 


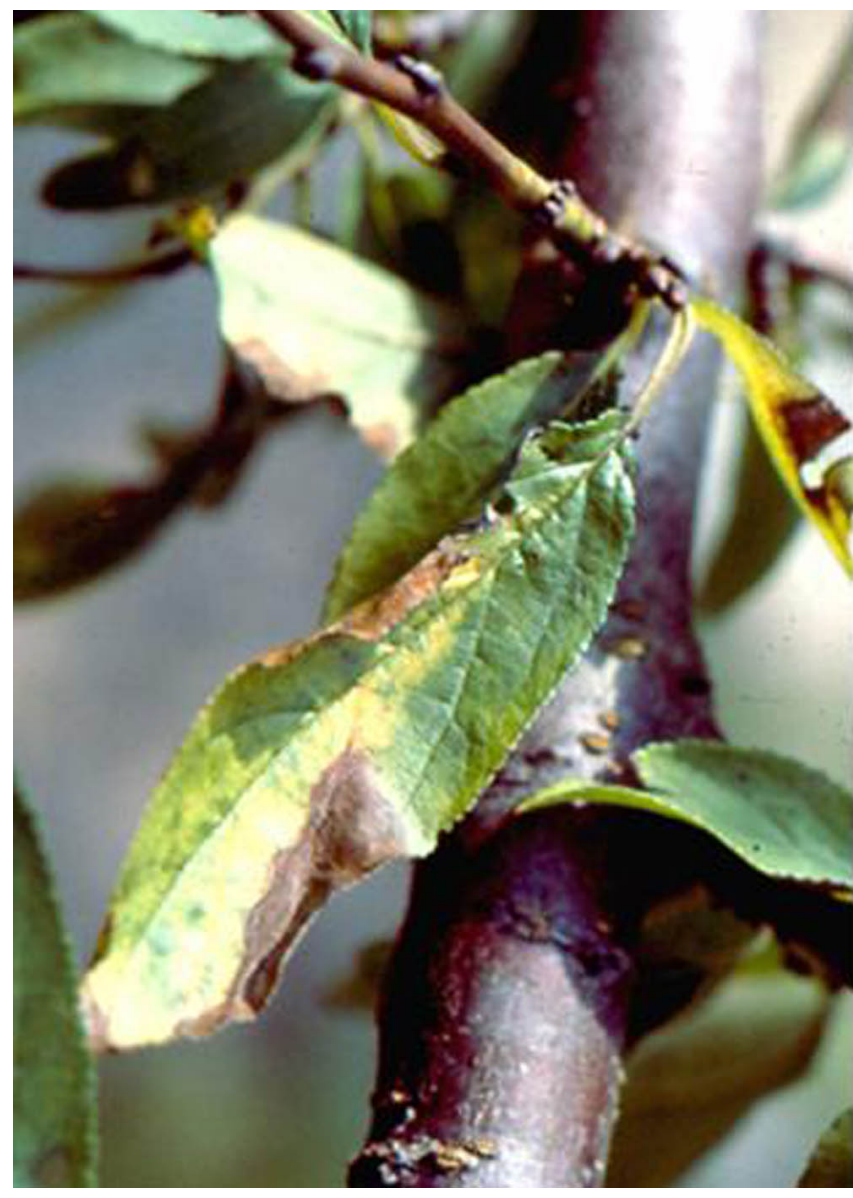

Figure 4. A plum leaf expressing systems of plum leaf scald disease.

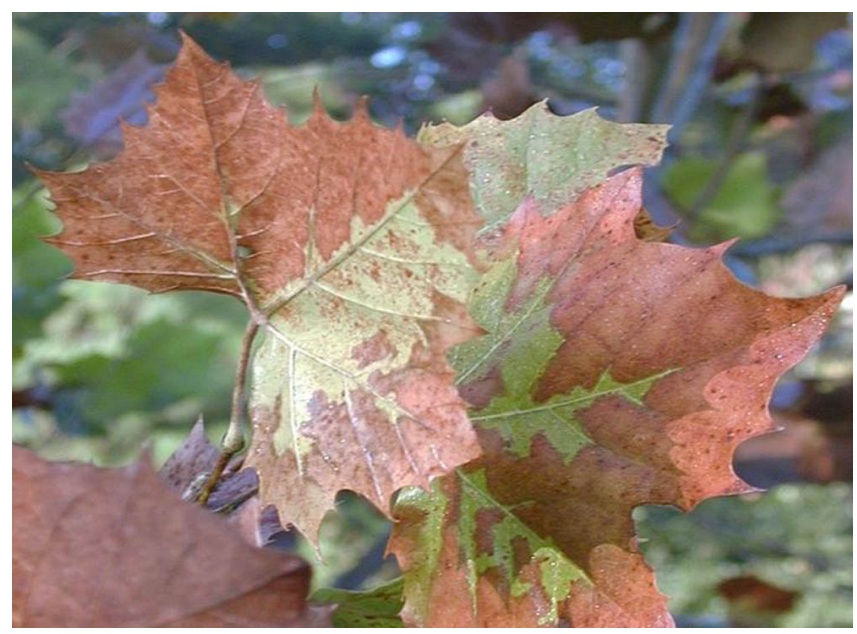

Figure 5. A sycamore leaf expressing systems of sycamore leaf scorch.

\section{Pierce's Disease}

Pierces disease has been the limiting factor in bunch grape production in Florida. The pathogen can be transmitted by grafting but natural spread is through the feeding activities of leafhopper vectors.
Symptoms are quite varied but involve a general loss in plant vigor followed by death of part or the entire vine. Specific symptoms include delayed leafing in the spring, shoot dwarfing, marginal scalding of leaves, leaf mottling and interveinal chlorosis and necrosis, wilting and premature coloring of fruit, uneven maturity of canes, and eventual death of the root system (Fig. 6). Different species and cultivars of grapes have a range of tolerance to PD. High susceptibility of premium wine grapes (Vitis vinifera) has virtually excluded a wine industry in Florida. Many muscadine grapes, however, are resistant to PD. Although X. fastidiosa will inhabit the xylem vessels of these cultivars, disease symptoms will not be expressed. Because of the range of susceptibility of grapes to $X$. fastidiosa, great care should be taken in selection of resistant cultivars (see below).

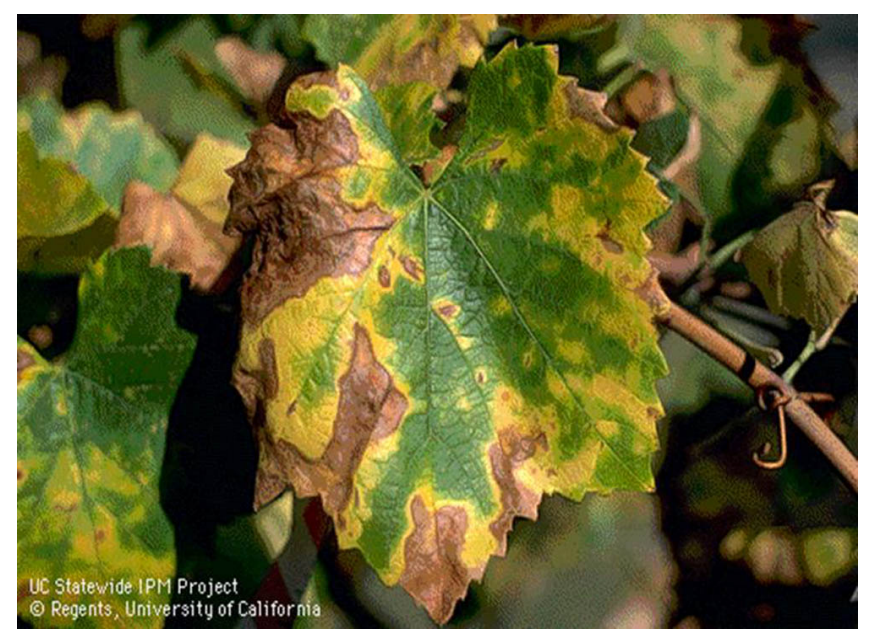

Figure 6. A grape leaf expressing systems of Pierce's disease. Credits: University of California

\section{Vectors}

The bacterium $X$. fastidiosa is spread primarily by a type of leafhopper known as sharpshooters (Fig. 2 and 7). The major insect vector in the coastal plain of the southeastern U.S. is probably the glassy-winged sharpshooter, Homalodisca coagulata, but other xylem-feeding insects including froghoppers and spittlebugs are considered to be potential vectors. Other leafhopper vectors include $H$. insolita, Oncometopia spp., Graphocephala spp. and Draeculacephala spp. (Fig. 7). These insects are commonly found in Florida in association with weeds, shrubs, and trees that serve as reservoirs for $X$. fastidiosa. Leafhoppers can become infectious after feeding on a diseased plant for a short period of time. 
The bacterium colonizes and survives in structures that are part of the mouthparts. Once the insect has acquired the bacteria, it can be spread to subsequent plants simply by feeding. Adult leafhoppers apparently remain infectious for life. Leafhoppers feed and oviposit (lay eggs) on an extremely wide range of plant species, but the adults and nymphs (Fig. 8) have different nutritional requirements. The number of plant species that enable complete leafhopper nymph development is much lower than the number of adult feeding hosts. Adult leafhoppers are strong fliers and can find and feed on hosts over a large area during their long lifetime. In mark-recapture experiments, $H$. coagulata was found capable of moving at least $180 \mathrm{~m}$ in a two hour period.

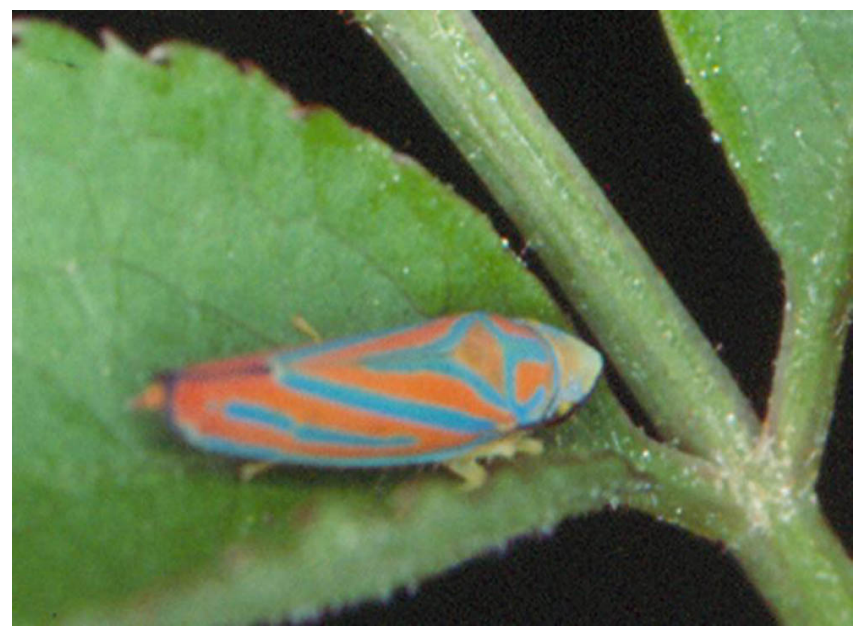

Figure 7. A leafhopper, Graphocephala sp., that vectors Xylella fastidiosa. Credits:

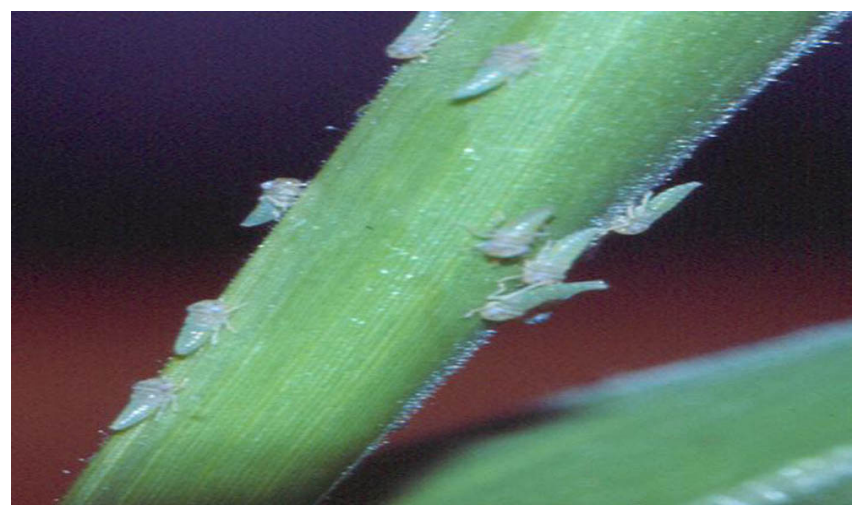

Figure 8. Nymphs of the leafhopper vector, Homalodisca insolita. Credits:

Over-wintering adults of $H$. coagulata do not hibernate, but their wintering behavior is not well understood. In winter, they feed on oaks, hollies and perhaps other hosts, and fly during warm spells.
Leafhoppers infected with $X$. fastidiosa have been collected almost every month of the year in Florida. The acquisition of the $X$. fastidiosa bacteria appears to have no effect on the insect vector.

\section{Vector/Host Plant interactions}

The greatest numbers of $H$. coagulata occur in fruit tree orchards in June in north Florida. Orchards with low intensity weed control and greater plant diversity will have higher numbers of leafhoppers. Healthy peach is usually not a favorite host plant of most leafhopper vectors and branches on trees displaying the symptoms of shortened internodes will not support $H$. coagulata. However, leafhoppers will feed on healthy peach after they have fed on infected weeds, spreading the disease agent. Other plant species such as crape myrtle, Lagerstroemia indica, native and domesticated plum, Prunus spp., grape, Vitis spp., sumac, Rhus sp., Baccharis halimifolia, and many other woody and herbaceous plants frequently serve as hosts for leafhopper vectors.

\section{Host Range of Xylella fastidiosa}

The full range of host plants for $X$. fastidiosa that causes PPD and other diseases is not known. $X$.

fastidiosa has a diverse host range encompassing over 30 families of monocotyledonous and dicotyledonous plants. Over 153 host species are known to harbor the bacterium. The bacterium is extremely widespread throughout the Southeast, although only a subset of plant hosts develops disease symptoms. For example, in a survey of woody plants conducted in Monticello, Florida by the authors, roughly half of the plant species examined were infected with $X$. fastidiosa. Moreover, a wide variety of bacterial strains exist, and only selected strains induce diseases in specific hosts (e.g., the PD strain will not cause disease if introduced to peach or plum). Laboratory tools have only recently been developed to detect and identify different isolates of $X$. fastidiosa. Wild and domestic plums are known reservoirs, but many plums are asymptomatic, or show few if any disease symptoms. Wild cherry, Prunus serotina, may be a minor host of PPD. Goldenrod is a host of $X$. fastidiosa, and future research will probably identify additional hosts. Johnsongrass, Sorghum halpense, which is a host of $X$. fastidiosa causing Pierce's disease in California, 
has been reported to contain the bacterium in Georgia where it does not cause PPD. Continued examination of alternative hosts suggests that we currently know only a small subset of the complete host range used by $X$. fastidiosa. The benign nature of the bacterium in many host plant species makes identification of host species difficult without molecular diagnosis. Research also suggests, unfortunately, that new problematic strains of $X$. fastidiosa may be developing, and unknown existing strains remain to be discovered.

\section{Recommendations}

Presently, there is no cure for PPD or any other disease caused by $X$. fastidiosa. Limited control efforts are directed toward preventing the spread of the disease. Effective control is difficult or impossible in areas of heavy infection.

\section{Peach/Plum}

Removal of diseased trees in two to five-year old peach orchards extends productive orchard life, although the underlying mechanism explaining this phenomenon remains unknown. Infected trees are readily identified by their reduced shoot growth in July and August unless trees are summer pruned. Rogue entire trees at the first sign of the disease. June and July is the best time to observe symptoms. Rogue out wild plums and cherries within 400 yards of the orchard. New plantings should be at least 400 yards from established plantings and should not include both peaches and plums. Control weeds in and about the orchard, since they may serve as reservoirs for both the bacterium and the vectors. Diseased trees should be identified and removed before an orchard is pruned. Avoid heavy summer pruning in June and July in North Florida. The subsequent regrowth after pruning is especially attractive to leafhoppers. Never plant a new orchard near an orchard showing PPD symptoms. Unfortunately, this has been tried with disastrous results. Maintenance of weed-free tree rows with an herbicide program and closely mowed sod 'middles' in orchards tends to reduce feeding and breeding plants for leafhoppers. This usually reduces their populations in the orchards; however, leafhoppers are strong fliers and can travel long distances to search for both hosts and mates.
Eliminate woods, particularly oaks and weeds, near the orchard whenever possible to minimize overwintering and alternate feeding sites for the leafhoppers. Routine spraying of orchards after harvest to control leafhoppers will not eliminate disease spread and is not cost effective. In a three-year program from 1948 through 1950, DDT was sprayed on a 1,000 acre (100,000 trees) orchard in middle Georgia. This program was judged a failure. Plots sprayed with parathion every other week during June and July in south Georgia also failed to show a consistent decrease in leafhoppers.

\section{Grapes}

Cultural practices suggested above, such as weed removal, will lessen exposure of grapes to leafhopper vectors and $X$. fastidiosa, but the primary line of defense is cultivar selection. Cultivars of Vitis vinifera will simply not survive in Florida. Many muscadine varieties, however, will exhibit partial to near complete resistance, and $X$. fastidiosa resistance should be considered in the selection of both grapes and rootstocks. Use Tampa, Dog Ridge, Lake Emerald, or Blue Lake as resistant rootstocks for bunch grapes. Muscadine grapes do not require rootstocks. The bunch varieties Blue Lake, Conquistador, Daytona, Lake Emeralds, Norris, Stover, and Suwannee are resistant to this disease.

\section{References Cited}

Andersen, P.C., B.V. Brodbeck and R.F. Mizell III. 1989. Metabolism of amino acids, organic acid, and sugars extracted from xylem fluid of four host plants by adult Homalodigca coagulata. Entomologia exp. appl. 50:149-149.

Andersen, P.C., B.V. Brodbeck and R.F. Mizell III. Feeding by the leafhopper Homalodisca coagulata in relation to xylem fluid chemistry and tension. Journal of Insect Physiology 38 (3): 611-622.

Andersen, P.C. and W.J. French. 1987. Biophysical characteristics of peach trees infected with phony peach disease. Physiological and Molecular Plant Pathology 31:25-40. 
Ball, J. C. 1979. Seasonal patterns of activity of adult leafhopper vectors of phony peach disease in North Florida. Environmental Entomology 8:686-689.

Brlansky, R. H., L. W. Timer, W. J. French, and R. E. McCoy 1983. Colonization of the sharpshooter vectors, Oncometopia nigricans and Homalodisca coagulata, by xylem-limited bacteria. Phytopathology 73:530-535.

Brodbeck, B., Mizell R.F. III, French, W.J., Andersend, P.C., Aldrich, J. H. 1990. Amino acids as determinants of host preference for the xylem feeding leafhopper, Homalodisca coagulata (Homoptera Cicadellidae). Oecologia 83:338-345.

Brodbeck, B., Mizell R.F. III, Andersen P.C. 1993. Physiological and behavioral adaptions of three species of leafhoppers in response to the dilute nutrient content of xylem fluid. J Insect Physiol 39:73-81.

Brodbeck, B., P. C. Andersen and R. F. Mizell, III. 1996. Utilization of primary nutrients by the polyphagous xylophage, Homalodisca coagulata, reared on single host species. Archives of Insect Biochemistry and Physiology 32:65-83.

Brodbeck, B., Mizell R.F. III, Andersen P.C., 1996. Differential utilization of nutrients during development by the xylophagous leafhopper. Homalodisca coagulata. Entomol Exp Appl 75:279-289.

Brodbeck, B., P. C. Andersen and R. F. Mizell, III. 1999. The effects of total dietary nitrogen and amino acid balance on the development of xylophagous leafhoppers. Archives of Insect Biochemistry and Physiology 42:37-50.

Davis, M. J., W. J. French and N. W. Schaad. 1981. Axenic culture of the bacteria associated with phony disease of peach and plum leaf scald. Current Microbiology 6:309-314.

Evert, D. R. 1985. Influence of phony disease of peach on the relationship between fruit weight and firmness near harvest. HortScience 20(1):87-88.

Evert, D. R. 1987. Influence of phony disease of peach on stem hydraulic conductivity and leaf xylem pressure potential. Journal of the American Society of Horticultural Science 112:1032-1036.

French, W. J. 1976. The incidence of phony disease in wild plum trees as determined by histochemical and microscopic methods. Proceedings of the Florida State Horticultural Society 89:241-243.

French, W. J. 1982. Reciprocal transmission of plum leaf scald and phony disease of peach. Phytopathology 72:452-453.

French, W. J., A. J. Latham, and D. L. Stassi. 1977. Phony peach bacterium associated with leaf scald of plum trees. Proceedings of the American Phytopathology Society 4:223.

Hopkins, D. L., H. H. Mollenhaur, and W. J. French. 1973. Occurrence of a rickettsia like bacterium in the xylem of peach trees with phony disease. Phytopathology 63:1422-1423.

Hopkins, D.L. and A.H. Parcell. 2002. Xylella Fastidiosa: Cause of Pierce's Diseas of grapevine and other emergent disease. Plant disease 86(10): 10546-1066.

Hutchins, L. M. 1933. Identification and control of the phony disease of the peach. Office of State Entomologist, State Capitol, Atlanta, Georgia. Bulletin 78, 55p.

Kenknight, G., H. J. Bruer, and C. E. Shepard. 1951. Occurrence of phony disease in wild plum thickets distant from peach orchards in Spartanburg County, S.C., USDA Plant Disease Reporter 35:183-185.

Mizell, R. F. and W. J. French. 1987. Leafhopper vectors of phony peach disease: feeding site preference and survival on infected and uninfected peach, and seasonal response to selected host plants. Journal Entomological Science 22:11-22.

Pollard, H. N. and G. N. Kaloostian. 1961. Overwintering habits of Homalodisca coagulata the principal natural vector of phony peach disease virus. Journal Economic Entomology 54:810.

Purcell, A. H. 1990. Homopteran transmission of xylem-limited bacteria. Pp. 243-266. In Harris, K. F. 
(ed.). Advances in disease vector research. Springer-Verlag. 367 pp.

Raju, B. C. and J. M. Wells. 1986. Diseases caused by fastidious xylem-limited bacteria and strategies for management. Plant Disease 70:182-186.

Sherald, J. L. and S. J. Kostka. 1992. Bacterial leaf scorch of landscape trees caused by $X$. fastidiosa. Journal of Arboriculture 18:57-63.

Turner, W. E. and H. N. Pollard. 1959. Insect transmission of phony peach disease. USDA Technical Bulletin 1183, 27p.

Turner, W. E. and H. N. Pollard. 1959. Life histories and behavior of 5 insect vectors of phony peach disease. USDA Technical Bulletin 1188, 28p.

Weaver, D. J., B. C. Raju, J. M. Wells, and S. K. Lowe. 1980. Occurrence in Johnsongrass of rickettsia like bacteria related to the phony peach disease organism. Plant Disease 64:485-487.

Wells, J. M., D. J. Weaver and B. C. Raju. 1980. Distribution of rickettsia like bacteria in peach, and their occurrence in plum, cherry, and some perennial weeds. Phytopathology 7:817-820.

Wells, J. M., B. C. Raju, J. M. Thompson, and S. K. Lowe. 1981. Etiology of phony peach and plum leaf scald disease. Phytopathology 71:1156-1161.

Wells, J. M., B. C. Raju, H. Y. Hung, W. G. Weisburg, L. M. Parl and D. Beemer. 1987. Xylella fastidiosa gen. nov.sp. nov.: Gram-negative, xylemlimited, fastidious plant bacteria related to Xanthomonas spp. International Journal. Systematic Bacteriology 37:136-143.

Yonce, C. E. 1983. Geographical and seasonal occurrence, abundance and distribution of phony peach disease vectors and vector response to age and condition of peach orchards and a disease host survey of Johnsongrass for rickettsia-like bacteria in the Southeastern USA. Journal Georgia Entomology Society 18:410-418.

Yonce, C. E. and C. J. Chang. 1987 . Detection of xylem-limited bacteria from sharpshooter leafhoppers and their feeding hosts in peach environs monitored by culture isolations and ELISA

techniques. Environmental Entomology 16:68-71 